\title{
Legumes are the key to increasing productivity at 'Inverary', a summer moist hill/high country farm in mid-Canterbury
}

\author{
John CHAPMAN ${ }^{1}$, Malcolm SMITH ${ }^{2 *}$, Richard LUCAS ${ }^{2}$, and Derrick MOOT ${ }^{2}$ \\ ${ }^{1}$ Inverary Station, Mt Somers, Canterbury, New Zealand \\ ${ }^{2}$ Dryland Pastures Research, Field Research Centre, Faculty of Agriculture \& Life Sciences, PO Box 85084, \\ Lincoln University, Lincoln 7647, New Zealand \\ *Corresponding author: malcolm.smith@lincoln.ac.nz
}

\begin{abstract}
About half the 4250 ha of Inverary is undeveloped mountain land above $750 \mathrm{~m}$ a.s.l. There are 300 ha of river flats, where lucerne and winter feed crops are grown, and 300 ha conventional grass/clover pastures. Limited areas of clover/plantain and winter feed crops have been established at $\sim 700 \mathrm{~m}$ a.s.1. on easy rolling country. The 1600 ha of steep country, dominated by browntop, gives low spring and high summer production that is difficult to manage. In 2009 , there were no lucerne or legume rich pastures. The legume emphasis increased animal productivity through improved lambing and lamb weight sold per ewe. Total lamb meat production lifted from 230,113 $\mathrm{kg}$ in 2009 to $245,039 \mathrm{~kg}$ in 2020 , despite 1000 fewer ewes. The current sheep to cattle ratio is $60: 40$ with 13,000 stock units being wintered. Pre-development, a major shortage of nutritious forage in early spring was compounded by difficulty controlling reproductive grass in summer and autumn. In 2016, total production of legume dominant pastures was $40 \%$ more than sown grass/clover pastures with limited nitrogen fertiliser (15 vs. $11 \mathrm{t} \mathrm{DM} /$ ha/year). In early spring, legumes had higher growth rates of conventional grass/clover pastures (90 vs. $44 \mathrm{~kg} \mathrm{DM} / \mathrm{ha} /$ day), whereas browntop dominant hill pastures grew $10 \mathrm{~kg} \mathrm{DM} / \mathrm{ha} / \mathrm{d}$ and $5 \mathrm{t}$ $\mathrm{DM} / \mathrm{ha} / \mathrm{yr}$.
\end{abstract}

Keywords: clover, plantain, steep, lamb production

\section{Introduction}

Inverary Station is located $10 \mathrm{~km}$ inland from Mount Somers township in mid-Canterbury in a summer moist 900 to $1000 \mathrm{~mm}$ rainfall zone. About half the 4250 ha property is higher altitude tussock grassland ( 750 to $1600 \mathrm{~m}$ a.s.1.) and unsuitable for pastoral development. Lucerne and winter feed are grown on the 300 ha of river flats. Most of the 300 ha of top flats and easy rolling country, at about $700 \mathrm{~m}$ a.s.l., was historically sown in conventional perennial ryegrass (Lolium perenne)/ white clover (Trifolium repens) pastures. More recently clover/plantain (Plantago lancelota), pure red clover (T. pratense) and some annual winter feed crops have been grown.
The 1600 ha hill country presents the greatest challenge to pastoral development. Introduced browntop (Agrostis tenuis) was dominant along with red fescue (Festuca rubra), Yorkshire fog (Holcus lanatus), sweet vernal (Anthoxanthum odoratum), native tussocks (e.g., Poa cita and Chionochloa sp.), with some patches of shrubland dominated by matagouri (Discaria toumatou), a native non-leguminous nitrogen $(\mathrm{N})$ fixer. Some of this hill country was developed during the 1960s and 70s from depleted tussock grassland with sparse sweet vernal, browntop, bare ground and hieracium (Hieracium pilosella) but negligible clover. Aerial oversowing and topdressing with superphosphate in early spring had immediate success, with the broadcast red clover and white clover seed establishing with little competition from the $\mathrm{N}$ deficient resident grasses. In the first few seasons, clover was 'shin high', suggesting up to $10 \mathrm{t} \mathrm{DM}$ /ha may have grown. Assuming these clovers fixed atmospheric $\mathrm{N}$ at a rate of approximately $30 \mathrm{~kg}$ $\mathrm{N} / \mathrm{t}$ of clover dry matter (DM) grown (Lucas et al., 2010), the growth of resident grasses would have been boosted by an input of $300 \mathrm{~kg} \mathrm{~N} / \mathrm{ha} / \mathrm{yr}$. Over subsequent decades, rhizomatous grasses have thrived on the back of this $\mathrm{N}$ boost and formed an extremely competitive, dominant vegetation cover, especially on the steeper hill country.

A comprehensive review of Inverary was initiated in 2016. It included analysis of livestock performance using 'StockCare' and 'Farmax' to consider issues relating to seasonal pasture production and livestock feed demand by the sheep and cattle breeding enterprise. Major mismatches between feed demand and supply were: 1) slow early spring pasture production, which limited lamb growth rates, 2) a major challenge to control rapid reproductive growth of grass dominant pastures in late spring/early summer, and 3) subsequent very low levels of pasture utilisation on the clover deficient, poor quality hill pastures. The quality declined further through autumn and winter, reaching low points of 5.5 MJ ME per kg of dry matter, which suppressed new season spring growth.

Difficulties in estimating seasonal pasture production on this steep hill country for Farmax modelling led to the decision to measure pasture production at over 30 


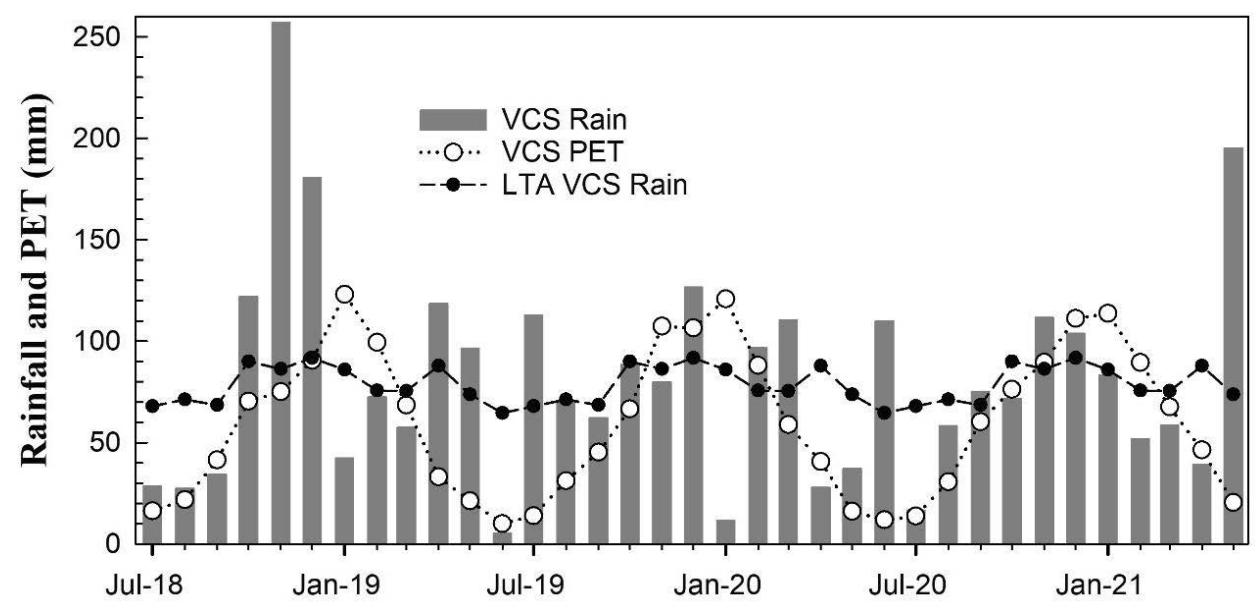

Month-Year

Figure 1 Total monthly rainfall and evapotranspiration (PET) from July 2018 to May 2021 at Inverary Station, Canterbury, New Zealand. Data, including 30-year (1990-2019) long term average (LTA) rainfall, from NIWA VCS at -43.675, 171.275 (NIWAData 2021).

sites. Results of pasture yield measurements in 2016 and three subsequent years (2018 to 2021) are presented. These are discussed in relation to future management of Inverary and the possibility of developing a sustainable legume-based pastoral system. The aim was to enable high beef and lamb growth rates with reduced carbon emissions per $\mathrm{kg}$ of meat and wool produced.

\section{Materials and Methods \\ Site characteristics}

Climate data were accessed from the NIWA Virtual Climate Station (VCS) at 43.675, 171.275 located on Inverary Station at an elevation of $637 \mathrm{~m}$ (NIWAData 2021). Long term average (LTA, 30-year average from 1991-2020) maximum and minimum air temperatures were 14.7 and $3.7^{\circ} \mathrm{C}$ respectively, annual rainfall was $940 \mathrm{~mm}$ with potential evapotranspiration (PET) of $720 \mathrm{~mm}$. LTA monthly PET exceeded rainfall from November to February with the highest difference of $30 \mathrm{~mm}$ occurring in January which indicates the farm is 'summer safe'.

The last three growing seasons (July to June) have been warmer than the LTA. In 2018-19, the VCS annual rainfall (July to June) was $1040 \mathrm{~mm}$, in 2019-20 it was $930 \mathrm{~mm}$, and in 2020-21 (July to May) was $865 \mathrm{~mm}$ (Figure 1).

At Inverary there were differences in the winter transitions into spring between the sunny (northerly facing) and flat or shady slopes. During September, soil temperatures were, on average, $2.6^{\circ} \mathrm{C}$ warmer on the sunny slopes than adjacent flat areas at elevations of $\sim 700 \mathrm{~m}$ a.s.l. (Table 1 ). The northerly slopes provided measurably earlier spring growth.

Severe winds, particularly from the north-west, can cause serious damage to emerging pasture and winter feed crop seedlings in spring and large losses of topsoil. Hence traditional cultivation is normally avoided and most seed is direct drilled.

Generally, soils at an elevation of $\sim 600$ to $770 \mathrm{~m}$ belong to the 'Brown' soil order that have a silt texture, are moderately deep (45 $\mathrm{cm}$ to $90 \mathrm{~cm}$ ), mostly stonefree, and well drained, with moderate to high water holding capacity. On the river flats, at an elevation of $460 \mathrm{~m}$, there was a large variation of soils. Closer to the foot of the hills, soils are 40-50 cm deep with high water holding capacity, but become significantly shallower $(20-40 \mathrm{~cm})$ towards the river at the lowest altitude. These soils were moderately stony with a silt texture, well drained with moderate to low soil water holding capacity.

At Inverary, $5 \mathrm{t} / \mathrm{ha}$ of agricultural lime was applied to areas of new pasture development, plus $300 \mathrm{~kg} / \mathrm{ha}$ of superphosphate. Maintenance fertiliser was applied annually as $200 \mathrm{~kg}$ sulphur superphosphate $(8 \% \mathrm{P}$ and $20 \% \mathrm{~S}$ ). Additional lime was applied when soil $\mathrm{pH}$

Table 1 Comparison of soil temperatures taken at 10 $\mathrm{cm}$ at different altitudes ( $\mathrm{m}$ a.s.I.) and aspects in September and October at Inverary Station.

\begin{tabular}{lcc}
\hline & \multicolumn{2}{c}{ Temperature $\left({ }^{\circ} \mathrm{C}\right)$} \\
\cline { 2 - 3 } Location (altitude) & September & October \\
\hline Sunny face $(700 \mathrm{~m})$ & 8.4 & 10.3 \\
Top flat $(700 \mathrm{~m})$ & 5.8 & 9.1 \\
Shady face $(650 \mathrm{~m})$ & 3.7 & 7.2 \\
Flats $(500 \mathrm{~m})$ & 7.1 & 10.4 \\
\hline
\end{tabular}


tests indicate it is required. Herbage testing of clover leaves during rapid growth in October/November was used to indicate the status of trace elements, such as molybdenum and boron and the adequacy of macronutrients, such as sulphur. Any deficiencies identified were corrected with appropriate additions to the maintenance fertiliser.

\section{Historical situation}

Attempts to improve hill country have been disappointing since the flush of clover achieved with aerial seeding and fertilising of hill country during the 1960s and 70s. At Inverary, some lucerne had been grown on the free draining river flats for conserved feed and grazing, plus forage crops to cope with the long winters when permanent pasture growth rates were negligible. Some conventional pasture was developed on the rolling country at $700 \mathrm{~m}$ a.s.l. by 2008 , but the possibility of improving the much larger area of hill country remained a major technical challenge.

Initially, incremental subdivision of the easier hill blocks gave pasture yield improvements but a fundamental problem remained whereby summer production increased substantially but there was still a lack of quality pasture in early spring during ewe lactation and at mating time in late autumn. Rotational grazing of these smaller paddocks resulted in some control of small areas, but the task of a significant wider control remained beyond the capacity of the livestock numbers available. The build-up of dead reproductive stems, old leaves and stolons of browntop was exacerbated by the ongoing deterioration due to climate, causing constant losses of quality through wet and drying, leaching and the winter freeze and thaw. Livestock lost significant weight when forced to eat it, or refused to eat it. In 2010, management was simplified by reducing ewe numbers from 6500 to 5500 , with a renewed effort to expand the area of quality pastures to finish lambs.

\section{System change}

It was decided that a new approach would leave grasses out of the mix, allowing any surviving or regerminating weed grass species to be selectively sprayed. This option will enable a grass component to be added in later years. In 2013, trial results from growing clovers and plantain were a revelation. In the second year, at the first clover/plantain pasture site, production exceeded $13 \mathrm{t} \mathrm{DM} / \mathrm{ha}$ of high-quality forage compared with 5-6 t DM/ha from the adjacent improved hill country browntop dominant pastures. Most importantly, spring and autumn production of the clover/plantain mix was three to four times the seasonal yields of the legume-deficient browntop dominant pasture. These had a summer peak production of $4 \mathrm{t} /$ ha of low-quality reproductive material. This result onfarm gave confidence to proceed with a more focussed attack on resident grasses as the way to achieve legume dominance. It was notable that the dead turf decayed in less than a year, assisted by the $\mathrm{N}$ from fixation of the vigorous white and red clovers.

In 2009 there were no pure legume, or even legumedominant pastures, on Inverary. By 2019, 260 ha were in production, including 50 ha lucerne. Of this area, around half was from conversion of existing conventional ryegrass dominant pasture and half from new development. This was enabled by direct drilling and a greater understanding and confidence in the ability of pure legume systems to pioneer change from low producing, thatch bound browntop pastures. In addition, a further 60 ha had transitioned one further step to high legume dominant pasture, often as plantain.

\section{Measuring the changes}

Pasture measurements started in 2013 and further measurements were recorded in 2016. A more comprehensive pasture sampling programme was carried out for three years from $1^{\text {st }}$ July 2018 to $30^{\text {th }}$ May 2021 in over 30 paddocks. Data were gathered by harvesting a $0.2 \mathrm{~m}^{2}$ quadrat from within exclosure cages, placed in strategic paddocks around the farm. Sites chosen represented paddocks from all the main land classification types.

Quadrats were cut every six weeks except for the winter period, when all the growth was harvested at the end of the three winter months, on or about 31 August. If there was too little pasture to measure in any of the cages after a 6-week interval, it was left to accumulate and harvested at the next cut. Pasture samples were cut using cordless sheep clippers to $20 \mathrm{~mm}$ stubble height, placed in a paper bag and stored at about $4{ }^{\circ} \mathrm{C}$. Soon after, samples were sorted into their botanical components (sown legume, sown grass, weed grass, broad leaf weeds and dead) and dried in a forced-air drying oven at $65^{\circ} \mathrm{C}$ for a minimum of $48 \mathrm{~h}$. Then each component was weighed and subsamples retained for analysis by near-infrared (NIR) spectroscopy (FOSS NIRSystems 5000) for ME, digestibility (D) and protein. Foliar N concentrations were calculated from the NIR protein content.

\section{Results}

In 2016, legume rich pasture types were over $40 \%$ more productive than grass dominant sown pastures (Figure 2).

Although the grass dominant pastures on Inverary received $40 \mathrm{~kg} \mathrm{~N} / \mathrm{ha}$ in spring and $40 \mathrm{~kg} \mathrm{~N} / \mathrm{ha}$ in autumn, the legume dominant pastures grew at $90 \mathrm{~kg}$ $\mathrm{DM} / \mathrm{ha}$ /day in early spring, double the $44 \mathrm{~kg} \mathrm{DM} / \mathrm{ha} /$ day in the grass dominant sown pastures. Improved hill 


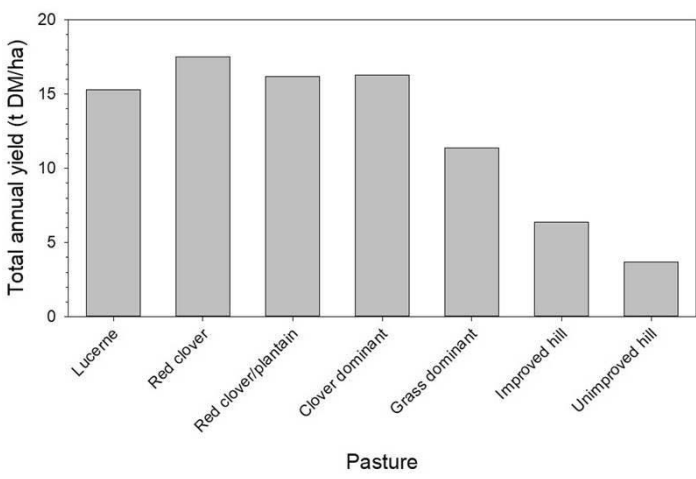

Figure 2 Annual dry matter yields for 2016 of different pasture types at Inverary Station. Note that the lucerne occupies the lightest, driest soils.

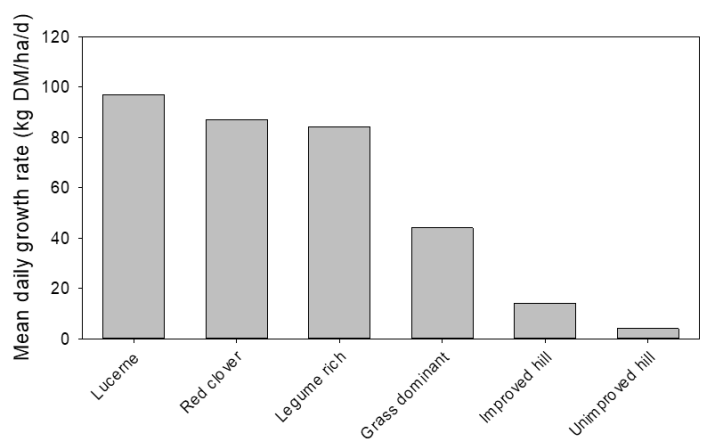

Figure 3 Mean early spring daily growth rates from 1st Spetmber to 15th October 2016 at Inverary Station.

pastures (oversown and topdressed) averaged only $9 \mathrm{~kg}$ $\mathrm{DM} /$ ha/day up to 15 October in 2016 (Figure 3).

Subsequent pasture measurements, averaged over three years, emphasised differences in total accumulated DM production between sown pastures (over $15 \mathrm{t} \mathrm{DM} /$ ha/year) and hill country (under $6 \mathrm{t} \mathrm{DM}$ /ha/year). The slopes of the spring growth curves show a clear difference between improved sown pastures and resident hill country dry matter production (Figure 4).

Table 2 shows the quality and nutritive value of the pastures grown in 2020/21 on the different land classes in spring, summer and autumn. The cultivated river

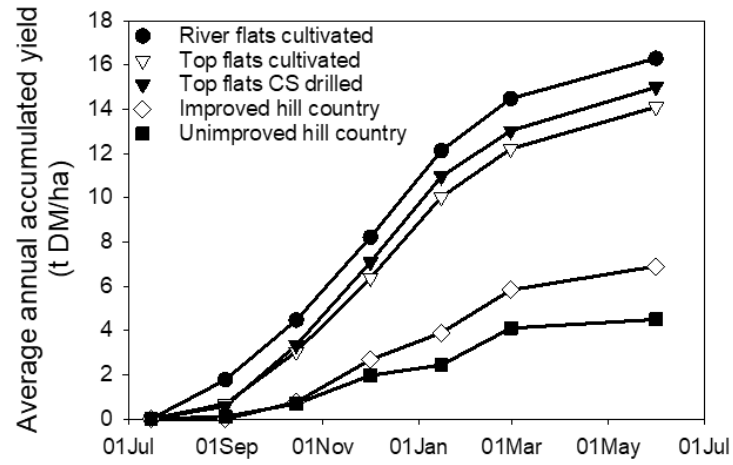

Figure 4 Three-year average annual accumulated pasture yield (2018/19-2020/21) from different land classes at Inverary Station.

flats, which grew lucerne, some grass/clover pastures and legume dominant pastures had a total legume proportion of about $60 \%$ throughout the year (Table $2)$. The paddocks in the top flats that were cross slot drilled and the top cultivated flats had values about $10 \%$ and $20 \%$ lower respectively, for spring and summer. However, in autumn, the former land class proportion lifted to match the river flats, whereas, for the top cultivated flats, the value dropped by $30 \%$. All of these values were exceptionally high for a hill country environment, and reflected the development that had occurred. The values for pastures on improved hill and unimproved hill paddocks were considerably less and followed expected trends. The ME and N\% values of all the pastures followed expected trends across all seasons.

The emphasis on legumes at Inverary was reflected in the increases in livestock productivity. In the years from 2009 to 2020, the average weight of lamb sold per ewe mated improved from 31.7 to $44.8 \mathrm{~kg}$, a $41 \%$ increase. The pregnancy scanning of the Romney based ewe flock lifted from $152 \%$ in 2009 to $165 \%$ in 2019 (Figure 6 a). Lamb wastage (lamb losses from scanning to tailing) reduced from $24 \%$ to $13 \%$ (Figure $6 \mathrm{~b}$ ) and lambs tailed to ewes mated improved from $113 \%$ to $133 \%$ over the same period. The improvements in the

Table 2 Average total legume, ME and N in pasture dry matter samples from different land classes at Inverary Station for spring, summer and autumn periods from the 2020/21 cage cuts.

\begin{tabular}{|c|c|c|c|c|c|c|c|c|c|}
\hline \multirow[b]{2}{*}{ Land class } & \multicolumn{3}{|c|}{ Total legume (\%) } & \multicolumn{3}{|c|}{ MJME/kg DM } & \multicolumn{3}{|c|}{$\mathrm{N} \%$} \\
\hline & Spr & Sum & Aut & Spr & Sum & Aut & Spr & Sum & Aut \\
\hline Cultivated river flats & 62.7 & 63.8 & 62.9 & 11.0 & 10.4 & 10.9 & 3.8 & 3.3 & 3.4 \\
\hline Top flats CS drilled & 52.7 & 57.9 & 62.4 & 11.0 & 10.8 & 11.1 & 2.3 & 3.2 & 3.9 \\
\hline Top flats cultivated & 42.9 & 45.6 & 29.8 & 10.9 & 10.6 & 11.4 & 3.3 & 3.2 & 3.3 \\
\hline Improved hill & 15.7 & 14.7 & 13.9 & 10.6 & 9.8 & 10.9 & 2.9 & 2.1 & 2.9 \\
\hline Unimproved hill & 6.4 & 5.7 & 4.8 & 10.0 & 9.8 & 10.3 & 2.5 & 1.9 & 2.7 \\
\hline
\end{tabular}


a)
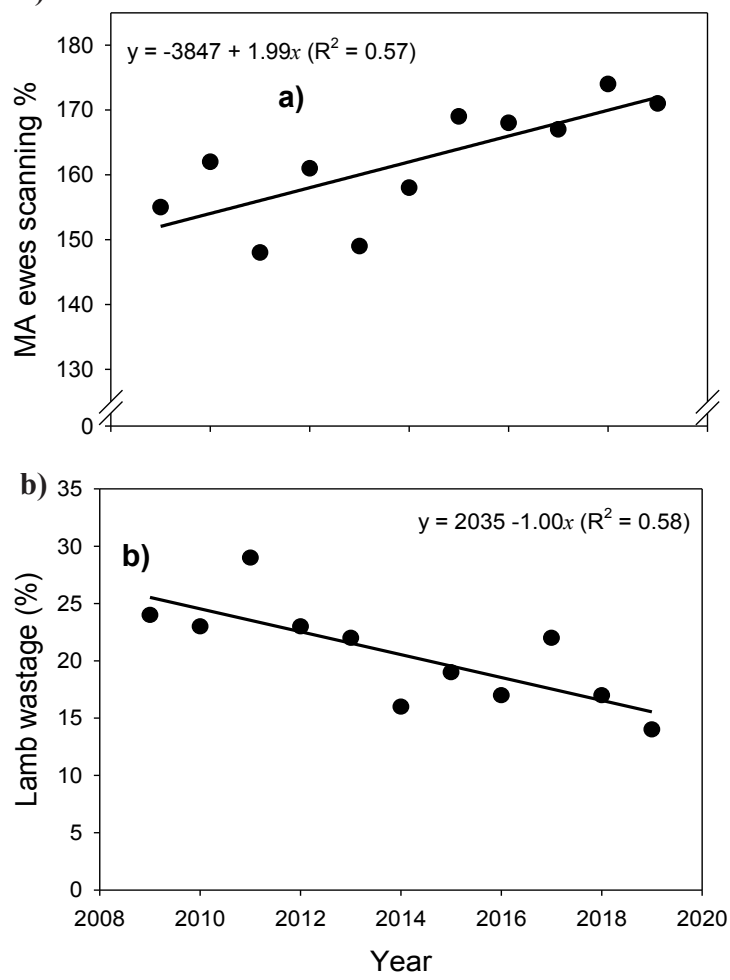

Figure 5 Change in a) mixed age (MA) ewes scanning \%, and b) lamb wastage \% from 2009 to 2019 at Inverary Station.

productivity of the ewe flock resulted in a 5\% increase in total lamb production, from $230,113 \mathrm{~kg}$ in 2009 to $245,039 \mathrm{~kg}$ in 2020, in spite at least 1000 fewer ewes, due to the sale of a 270 ha irrigated finishing property.

\section{Legume species and pasture longevity at Inverary}

The introduction of legume dominant pastures over the last 10 years mitigated the early spring pasture deficit which had been an on-going influence on the ability to control reproductive growth, maintain pasture quality and increase utilisation. The high proportion of legumes available, especially in early spring, has seen a steady increase in livestock productivity. Over the last three years, this enabled the mating date for half of the ewe flock to be brought forward one complete cycle. After a successful pilot last year, half of the ewe hoggets have been mated this year, at a minimum weight of $45 \mathrm{~kg}$. Lamb growth rates, total annual weight of lamb sold, and ewe reproductive measures all benefitted from the introduction of legume or legume-dominant pastures. The mix of legumes used at Inverary was designed to match the land class and expected seasonal growth rates.

Lucerne was used on the free draining river flat soils where aluminium toxicity in the sub-soil was absent.
It was primarily harvested for hay and silage and then grazed later in summer /autumn. Stands last about 10 years, but the land requirement for annual winter feed crops may mean the accumulated $\mathrm{N}$ fertility from lucerne stands can be exploited sooner.

Red clover has been the vital pioneer legume in the initial development of new areas. It replaced the more conventional cereal green-feeds, that needed significant $\mathrm{N}$ fertiliser to enhance the breakdown of the browntop turf. Monocultures of red clover without grasses fix large amounts of nitrogen that is then urinated out from animals onto the carbon dominant thatch to hasten its decomposition. The red clover provided nutritious early spring feed at the start of lactation. The threeto-four-year lifespan of red clover generally results in white clover becoming dominant during year three. The rotational grazing of red clover allowed control of invasion of grass weeds with selective herbicides. It is probable that the legume phase provides a period in which the seedbank of rhizomatous grasses diminishes.

On an easy contoured group of paddocks, a sevenyear rotation is now developing after the initial threeto-four-year red clover phase. Short rotation ryegrass was drilled into the legume rich sward for two years, followed by a brassica, such as radish, in year seven.

White clover was present over much of the developed areas of the property and included with red clover in new pasture sowings. In this summer safe environment, white clover provides a strong clover base in new pastures until resident grasses invade. It formed a valuable backup to red clover in Years 3 and 4 of the new pasture developments and can regenerate from seed reserves in the soil.

Caucasian clover (Trifolium ambiguum) presented establishment challenges, but efforts to exploit its longevity and tolerance of glyphosate have shown promise at Inverary. It is more competitive than white clover against weed grass invasion and associates well with plantain as a permanent pasture.

Perennial lupin (L. polyphylus) /Russell lupin was established successfully in new pasture in spring 2020 with red clover, white clover, plantain and cocksfoot. Russell lupin is more tolerant of Al toxicity than white clover and red clover, and more efficient in its use of phosphorus.

Maku Lotus (Lotus pedunculatus) is tolerant of low $\mathrm{pH}$ soils and was present amongst snow tussocks and on stream banks on less developed areas of Inverary, which presumably means it survived since its introduction in the 1980s.

Annual clovers and Sub clover was sown on at least three Inverary paddocks with variable success. This 'summer safe' environment (Figure 1) suggested only eight weeks when evapotranspiration exceeds mean rainfall, which may not be sufficient to justify persisting with it, unless summer dry spells get longer. 


\section{Future Production}

Livestock performance continues to improve on Inverary as total legume production increases. Modification of livestock policies are now possible, with the improved feeding value of early spring pastures. Lambing earlier than mid-October can be contemplated, pre-weaning lamb growth rates of $300 \mathrm{~g} /$ lamb/day are achievable, live-weight of lambs weaned per ewe mated could make further increases and/or ewe numbers could increase. Early weaning is being considered, so weaned lambs are not competing with ewes for elite pastures. Ewes would be used to control grass reproductive development earlier than at present. Greater control of developed hill pastures, with more frequent intensive grazing, is expected to result in overall hill pasture improvement. Improvements in early spring pasture quantity and quality have already been shown as increases in ewe condition at mating.

In general, grass/clover pastures become grass dominant after only a few years of $\mathrm{N}$ fixation from the associated clovers. However, some grasses such as timothy (Phleum pratense) are less competitive, and herbs such as plantain encourage legume growth to extend the legume phase. The experience at Inverary indicated that reduced sowing rates of a suitable grass, such as timothy, combined with plantain, can extend the legume dominant phase longer than is possible from a cocksfoot or ryegrass/clover pasture. Furthermore, plantain has shown the ability to persist and reseed under normal grazing management. After eight years of observations, it is clear that legume and legumeplantain pastures are significantly higher producing in all seasons (about $15 \mathrm{t} \mathrm{DM} / \mathrm{ha} /$ year) than more conventional grass/clover pastures $(11 \mathrm{t} \mathrm{DM} /$ ha /year).

\section{The future of legumes at Inverary}

Lucerne has a valuable function at Inverary as a finishing feed and a hay and silage option. Unfortunately, the area with acceptable Al levels that was suitable for lucerne is restricted, and other legumes have become the focus. A system is evolving at Inverary where there are three clear uses of legumes which are determined by the contour of the site and the existing cover.

1) As a development tool - a transition phase to grass based pastures

2) As a specialist pasture role for optimising livestock production.

3) Ongoing use in conventional pasture

\section{Legumes as a development tool}

Where steeper country is involved, there is a corresponding increase in difficulty and expense, particularly where fertiliser, lime and weed sprays have to be applied by air The return of weed grasses is almost certain and may be controlled initially by the use of chemicals, but this is not seen as an appropriate long term option The relatively short life of a red clover/ white clover/plantain pasture is seen as a transition, but it does enable the establishment of a more aggressive pasture grasses, such as cocksfoot, to counter the reinvasion of browntop and red fescue. While this subsequent conventional pasture will not have the spectacular production attributes of the legume phase, it will still be on a quite different level to the original browntop sward.

\section{Legumes as a specialist pasture and their legacy contribution}

The more easily contoured paddocks provide a site for specialist legume pastures to optimise animal production, and provide $\mathrm{N}$ that promotes outstanding growth of subsequent crops. These areas are less costly to establish, more straight forward to fertilise, lime, subdivide and keep weed free, either by spray or manually. They are the most productive soils and have much less weed seed offering to reinvade. A six-toseven-year rotation is developing - beginning with the initial three-to-four-year red clover development phase. As legume productivity begins to decline, short rotation ryegrass is drilled in to the legume sward for one or two years with a brassica crop to follow. The ongoing production from these rotations are hugely productive. Over the entire rotation, the production level is at least $50 \%$ higher than adjacent conventional pasture and of significantly higher quality.

\section{Environmental considerations - carbon output and climate change}

Greater use of legumes has significantly decreased the need for nitrogenous fertiliser, which is now regarded as a tool to use in difficult seasons, rather than a standard requirement of spring and autumn pasture production. The gains in total lamb production have been achieved by increases in per head production rather than increased numbers of breeding stock. There are now 1000 fewer ewes at Inverary compared with 10 years ago. However, the weight of lamb produced per ewe from the remaining ewes has risen by $41 \%$ due to increases in scanning, survivability and improved growth rates from birth to weaning. The successful adoption of hogget lambing is likely to improve this figure further.

Similarly, post weaning growth rates have improved dramatically. Typically, the expected growth rates on ryegrass dominant pasture 10 years ago were less than $100 \mathrm{~g} /$ head/day. StockCare data records show that the lambs grew on average $184 \mathrm{~g}$ /day last year, compared with an average of $125 \mathrm{~g}$ /day in the top quartile of over one hundred Stockcare properties. The carbon emissions per unit of meat or wool output will 
be reduced from faster growing young stock which remain on the property for a shorter time (de Klein et al., 2008). This means that they will not be present or require as much finishing in the deeper and drier summers expected in future.

The increase in total area of developed country and the use of legumes has led to an increase in the total pasture grown at Inverary. This is much more efficiently utilised, and the carbon cost per unit of product produced has reduced, Inverary is aware of its responsibilities to the overall impact of the farming operation, and a 100 hectare Douglas Fir forestry block on the property is in the planning stages.

\section{Conclusions}

It is obvious that there have been some outstanding production increases at Inverary over the last 10 years. However, it is difficult to isolate the exact contribution of the legume development. Other factors, such as increased subdivision, improvements in management and genetics have contributed but they cannot account for the magnitude of the changes that have occurred. In 2009 there were no pure legumes on Inverary, but, by 2019,260 ha were in production with a further 50 ha of lucerne. A further 60 ha were transitioned to high legume dominant pastures, often with plantain. Legumes have been the driver of the transformational change at Inverary.

The practical implications of these conclusions are relevant to a large area of summer moist, South Island hill and high country. The continued development of legumes in hill pastures will enable faster animal growth rates with an objective of reducing the carbon emissions $/ \mathrm{kg}$ of meat or wool produced.

\section{ACKNOWLEDGEMENTS}

Thanks to Bert Oliver, Inverary Station manager and his staff, Drs Sonya Olykan and Annamaria Mills for valuable assistance in preparing this paper. Funding for this project and manuscript preparation was provided by DairyNZ, Beef + Lamb New Zealand, MBIE, Seed Force New Zealand and PGG Wrightson Seeds under the 'Hill Country Futures' research programme (BLNZT1701).

\section{REFERENCES}

de Klein CAM, Pinares-Patino C, Waghorn GC. 2008. Greenhouse gas emissions. In: McDowell RW Ed. Environmental impacts of pasture-based farming. Wallingford, UK: CAB International. pp. 1-33. https:// doi.org/10.1079/9781845934118.0000.

Knowles IM, Fraser TJ, Daly MJ. 2003. White clover: loss in drought and subsequent recovery. In: Moot DJ Ed. Legumes for Dryland Pastures. Grassland Research and Practice Series 11: 37-41. https://doi.org/10.33584/ rps.11.2003.2997.

Lucas RJ, Smith MC, Jarvis P, Mills A, Moot DJ. 2010. Nitrogen fixation by subterranean and white clovers in dryland cocksfoot pastures. Proceedings of the New Zealand Grassland Association 72: 141-146. https:// doi.org/10.33584/jnzg.2010.72.2825.

Morton JD, Moir JL. 2018. Soil aluminium toxicity in New Zealand pastoral farming - a review. Journal of New Zealand Grasslands 80: 129-138. https://doi. org/10.33584/jnzg.2018.80.318.

NIWAData. 2021. VCSN climate data for -43.675 , 171.275. Retrieved 08/06/2021 from: https://data.niwa. co.nz. 